\title{
DOES HISTORY REPEAT ITSELF?: THE IDEOLOGY OF SADDAM HUSSEIN AND THE MESOPOTAMIAN ERA ${ }^{1}$
}

\author{
Umangh Harkhu \\ Department of Ancient Studies \\ Stellenbosch University
}

\begin{abstract}
Present-day Iraq occupies the area that was once the heartland of the ancient civilization of Mesopotamia. Despite the millennia that separate Mesopotamia and the Iraq of Saddam Hussein, several aspects of the deposed Iraqi leader's ideology (including his concept of warfare) seem to bear a remarkable resemblance to the ideology of the kings of ancient Mesopotamia. This article explores this resemblance and shows that while Saddam Hussein and the Mesopotamian kings had much in common, there were several differences as well. Furthermore, the many empires that followed Mesopotamia also left their mark on modern Iraq. History may have, to an extent, repeated itself in that Saddam Hussein perpetuated many of the traditions associated with the kings of Mesopotamia, but his ideology reflected his specific conditions - conditions different to those that existed in the Mesopotamian era.
\end{abstract}

\section{Introduction}

This article evaluates the similarities between the royal ideology prevalent in ancient Mesopotamia (present day Iraq) ${ }^{2}$, from the fourth millennium ${ }^{3}$ until its incorporation into the Achaemenid empire in 539BC, and that of the regime of

\footnotetext{
${ }^{1}$ This article is the result of research done for a MPhil degree in Ancient Cultures at the Stellenbosch University.

${ }^{2}$ The source material for ancient Mesopotamia is problematic and there is still uncertainty in reconstructing certain phases of that country's history. Kuhrt (1997:10) points that not all periods are equally represented in the evidence, or equally understood.

${ }^{3}$ All dates relating to Mesopotamia are BCE.
} 
Saddam ${ }^{4}$, who from 1979 until recently controlled Iraq. Sciolino (1991:82) has likened Saddam's Iraq to Hammurabi's (1792-1750BC) ${ }^{5}$ realm and Simmons (1994:xiv) refers to Saddam as heir to Nebuchadnezzar II (604-562BC). Saddam has also portrayed himself as some of the most powerful Mesopotamian kings.

Space does not permit detailed historical accounts of the two periods under discussion although such accounts would have been useful. Some historical framework is nonetheless required so that the discussion that follows may be seen in context. To this end, the three tables below might be of value:

TABLE 1: MAJOR PERIODS IN MESOPOTAMIAN HISTORY (4000 - 539BC)

FOURTH MILLENNIUM

Uruk Period

c. $3500-3000$

THIRD MILLENNIUM

Early Dynastic Period I

c. $2900-2700$

Early Dynastic Period II

c. $2700-2600$

Early Dynastic Period III

c. $2600-2400$

Empire of Akkad

c. $2340-2159$

Third Dynasty of Ur (Ur III)

c. $2112-2004$

\section{SECOND MILLENNIUM}

Old Assyrian Period (northern Mesopotamia)

c. $2000-c .1800$

Old Babylonian Period (southern Mesopotamia)

c. $2000-$ c. 1800

Middle Babylonian Period (southern Mesopotamia)

c. $1600-1000$

Middle Assyrian Period (northern Mesopotamia)

c. $1400-1050$

\section{FIRST MILLENNIUM}

Neo-Assyrian Empire

c.934-610

Neo-Babylonian Empire

c.626-539

\footnotetext{
${ }^{4}$ Pollack (2002:429) notes that there is some confusion about the proper shorthand for Saddam Hussein's name. He points out that the correct shorthand is 'Saddam', not 'Hussein' which is merely Saddam's father's first name, not Saddam's family name.

${ }^{5}$ All dates relating to the ancient kings reflect their years of rule. Dates relating to modern figures reflect their dates of birth and, if applicable, death.
} 
Scientia Militaria, South African Journal of Military Studies, Vol 33, Nr 1, 2005. doi: 10.5787/33-1-3

TABLE 2: PERSIAN CONQUEST TO IRAQI INDEPENDENCE: MAJOR EVENTS

(539BCE - 1932CE)

PERSIAN RULE

c. $539-333$

ALEXANDER AND HIS SUCCESSORS c.332-143

PARTHIAN CONTROL

143BCE-240CE

SASSANIAN CONTROL

240-637

CONQUEST BY ARABS

637

OTTOMAN CONTROL

$1533-1918$

IRAQ ENTRUSTED TO THE BRITISH

1920

IRAQ GAINS INDEPENDENCE

1932

TABLE 3: IRAQ FROM 1937 - 2003: MAJOR EVENTS

SADDAM IS BORN

$1937^{6}$

COUP LED BY GENERAL QASSIM

1958

FIRST BA'ATH REGIME REPLACES QASSIM

1963 (FEB)

BA'ATH REGIME IS OVERTHROWN

$1963(\mathrm{NOV})$

BA'ATH PARTY IN POWER AGAIN

1968

SADDAM BECOMES PRESIDENT

1979

IRAN-IRAQ WAR

1980-1988

GULF WAR I

1990-1991

ALLIED FORCES INVADE IRAQ ${ }^{7}$

2003 (MAR)

SADDAM IS CAPTURED

2003 (DEC) 


\section{Royal ideology: ancient and modern}

Several aspects of the ruler ideology of the two periods in question have been identified that bear apparent similarities in spite of the enormous time-span between them. Each of these aspects will be examined separately, beginning with the ancient ideology, followed by that of Saddam.

\section{Absolute power of the ruler}

Towards the end of the Uruk period, writing appeared for the first time. During this period huge ceremonial complexes appeared that were built from imported materials and decorated with sophisticated art-works. There is also evidence of the emergence of substantial urban communities with developed socioeconomic structures. All of these facts point towards a highly evolved political system with a ruler at the head of this society (Kuhrt, 1997:25). The figure of the ruler dominates many of the pictorial scenes of this period and it appears that the important ideological activities of the state were in his care and under his control (Kuhrt, 1997:25).

With the building of a large empire, the image of the Akkadian king was presented in a new light: 'he would no longer be that good-natured and easily accessible petty king, but the proud and haughty chief at the head of a huge region, of a large collection of people, henceforth existing well above the masses, governing them all from above in his quasi-supernatural majesty, and simultaneously evoking admiration, prostrations, and fear' (Bottero, 2001:13).

In the administration of their realm, the kings of the Ur III state regularly rotated governors to new assignments as a means of preventing them from becoming too powerful in their provinces (Knapp, 1988:94). In order to strengthen central government at the expense of local power, the kings relocated the populations of conquered cities to other areas. Both these practices became common in the empires of the first millennium.

By the Neo-Assyrian period, the king was the central figure around which the entire empire was organized. He was both chief of state and commander of the army. The building of an empire resulted in the development of a kingship, which culminated in absolute royal power. The king was an autocrat and his power was unchallengeable. All nominations to office were totally dependent on royal favour. Furthermore, the king held the power of life or death over all his subjects who owed total loyalty to him. 
During the reign of Tiglath-pileser III (744-727BC), those who enjoyed independent power bases due to their aristocratic lineage or large landholdings were kept in check or eliminated. The Neo-Babylonian kings, like their immediate predecessors, were also absolute monarchs that headed the administration, army, religion and court. Extensive security and spy networks were created by these kings with agents reporting to them any signs of disaffection and intrigue (Postgate, 1977:25). Finally, in Mesopotamia, constitutional organs for collective expression of the popular will were largely absent (Hallo \& Simpson, 1998:175), and it would seem that as a ruling autocrat, the position of the Mesopotamian king became more extreme as time went on and the size of the kingdoms increased.

Saddam, whose name means 'the one who confronts', was born in 1937. At the age of twenty he joined the anti-government Ba'ath Party. One of the core beliefs of the party was that all Arabs belonged to a single nation, which must be unified politically. The Ba'ath Party eventually gained control of the country in a coup in July 1968. Saddam soon became the second most influential person in Iraq after President Bakr (1914-1982) who had chosen him as his right hand man (Karsh \& Rautsi, 1991:35). In 1979 Saddam forced his superior into 'retirement' on the alleged grounds of poor health (Karsh \& Rautsi, 1991:85), and it could be said that Saddam, like so many of the Mesopotamian kings, seized control of the country.

From 1968 until Saddam's fall, the government had been a dictatorship dominated by the only officially recognized party, the Ba'ath Party. The people, like the ordinary Mesopotamian citizens, had no voice in government. Saddam held all the country's top posts (President of the Republic, Chairman of the Revolutionary Command Council, Secretary-General of the Ba'ath Party Regional Command, Prime Minister and Commander of the Armed Forces), in much the same way as the Mesopotamian monarchs headed all the important institutions of the land.

Like the Mesopotamian kings, Saddam ensured that no one became either too prominent or too popular. Anyone who did so was jailed, murdered, or if lucky, simply relieved of his post. In 1982 he also reshuffled the country's major power centres (Karsh \& Rautsi, 1991:165). Army officers were frequently moved from unit to unit to prevent them from becoming too close to their troops (Coughlin, 2002:203). By the 1990s Saddam had established one of the most extensive security structures in modern history (Coughlin, 2002:297) just as the Mesopotamian kings established theirs in antiquity. Saddam's regime had scores of regular informants who were rewarded for reporting suspicious activities. It should be pointed out that in Saddam's Iraq, the government had available to it much more developed technologies and techniques enabling it to reach society to a far greater degree than the rulers of Mesopotamia ever did. Hiro (2002:58) describes how far-reaching and 
sophisticated Saddam's intelligence service was. ${ }^{8}$ It reached every neighbourhood, every town and every rural district (Pollack, 2002:119). In contrast, while the Mesopotamian kings maintained tight control over the cities and surrounding countryside, they were unable to penetrate the peripheral areas to any real extent and their control there was relatively loose.

Sciolino (1991:51) notes that despite the Ba'ath Party's egalitarian rhetoric, Saddam really wanted to be king. At the end of the Iran-Iraq War in 1988, he took several steps to rehabilitate the notion of monarchy in Iraq, including the publishing of several official books praising the monarchy and renovating Baghdad's royal cemetery, at the cost of three million dollars. During this time Saddam assumed an air of grandeur and pomp. He saw himself as the living embodiment of Iraqi history: 'The assumption of this weighty historical and noble legacy seemed to assert to his people and to the world that his rule was predestined and inviolable, part of a multimillennial chain' (Karsh \& Rautsi, 1991:196). Furthermore, Coughlin (2002:298) reports that Saddam's meetings with visiting dignitaries at his palaces took the form of a royal audience. Guests were supposed to talk only after he had spoken, and then to keep their answers concise.

One of the ways of exerting control over rebellious groups who threatened the absolute power of the president was to deport large numbers to another area, a method also favoured by the Mesopotamian kings. One example of this practice during Saddam's rule occurred during the time of the Iran-Iraq conflict when more than half the towns and villages in Kurdistan were destroyed and their populations deported to the main towns or to concentration camps in the Iraqi desert (Coughlin, 2002:224-225).

\section{Violence and terror}

Ancient Mesopotamia has seen numerous kingdoms and empires. Aburish (2002:64) notes that while some of these entities expanded and then contracted, often to disappear of their own accord, most of them replaced each other violently through rebellion or conquest or a combination of both. Mesopotamia was a land formed by fear - fear of the flooding of the rivers, fear of war, fear of the gods and fear of the king. Sargon II (721-705BC) said of himself: 'I left behind a terror never to be forgotten' (Holloway, 2002:80). This fear and terror that the kings evoked was an important aspect of royal ideology.

\footnotetext{
${ }^{8}$ Saddam's security apparatus was developed in part, with the assistance of the (former) Soviet Union's KGB.
} 
Kuhrt (1997:517) describes the Assyrian kings as 'awe-inspiring: the fear that filled his enemies was the terror of those knowing that they will be ruthlessly, but justly, punished'. Younger (1990:66) points out that in the absence of mass media of communication, terror, spreading from village to village, and from town to town, was the only means of softening up an enemy in advance.

Like the ancient kings who strove to hold their empires together, Saddam had to weld together a fragmented country, created by Britain out of three ex-Ottoman provinces. Saddam used fear and terror to do so. Iraq did not have the national bonds of ethnicity or religion. The Kurds in the north wanted independence. They were Sunni Muslims but not Arabs. The Shi'ites of the south made up most of the population. However, power was in the hands of the Sunni minority of which Saddam was a non-practicing member ${ }^{9}$ (Ramesh, 2003:123).

From its conception the Ba'ath was a violent party in Iraq beginning as a revolutionary underground guerilla organisation that equated violence with heroism (Sciolino, 1991:48). Miller and Mylroie (2003:28) have this to say of Saddam: 'He had replaced the state with the (Ba'ath) party, and (then) the party with himself, the giver of life and death. The terror that was his to dispense would make people fearful, but it also inspired awe, and in a few, the appearance of mercy would even evoke gratitude'. This description applied equally well to the Mesopotamian kings, particularly those of the Neo-Assyrian empire. Sciolino (1991:253) reports that during the invasion of Kuwait, hundreds of unarmed civilians, including children, were tortured or executed. Some of the victims were burned by acid or acetylene torches, others had their ears or noses cut off or eyes gouged out. Indeed Saddam, like Sargon II, left behind a terror never to be forgotten.

It must be noted though, that violence in the region was not restricted to the two eras in question. Simpson (2003:39) notes that Iraq has always had a reputation for political instability and is a land where violence and cruelty are commonplace. In the fourth century BCE, Alexander the Great (332-323) conquered the region. In the eight century $\mathrm{CE}$, it was conquered by Arab Muslims who established the Abbasid caliphate. The empire was characterized by violence: no less than eighty of its ninety-two caliphs were murdered as a result of feuds over succession, corruption or intrigues (Aburish, 2002:65).

In 1258 Mongols stormed Baghdad and killed the caliph by rolling him in a carpet and then trampling him under the hooves of their horses (Murray \& Scales,

\footnotetext{
${ }^{9}$ The division between Shi'ite and Sunni began when Shi'ite Muslims broke away from the Sunni mainstream in the seventh century in a dispute over whom should succeed the Prophet Mohammed after his death.
} 
2003:17). When the Mongols returned a century later, they massacred the city's citizens leaving behind a carefully constructed pyramid of skulls (Murray \& Scales, 2003:17). In the seventeenth and eighteenth centuries Iraq was the battleground between Persians and Ottoman Turks who fought for control of the region. Iraq was eventually incorporated into the Ottoman empire. After the defeat of the Turks in the First World War, Britain occupied Iraq. Thereafter the country became a monarchy of Britain's creation. When the Hashemite dynasty which had ruled Iraq since its inception in 1921 was overthrown by a military coup in 1958, led by General Abd al-Karim Qassim (1914-1963), the Iraqi regent was dragged by a mob through the streets of Baghdad before being hung at the gate of the Ministry of Defence (Karsh \& Rautsi, 1991:3). In turn, Qassim's bullet-ridden corpse was screened on Iraqi television when he was overthrown (Karsh \& Rautsi, 1991:4).

Aburish (2002:65) asserts that the violence and cruelty which accompanied every change in the leadership of the country throughout its long history left an indelible imprint on the local population. The various regions and tribes of Iraq, all through its history, had been unified by force - by the ancient Mesopotamian kings, by the Ottoman and British empires, by the Hashemite monarchy, by the Ba'ath Party, and finally, by Saddam.

Saddam, in contrast to earlier political orders was, through technology and his various security services, able to extend his reach to a far greater extent. His ability to control the entire population was also greater ${ }^{10}$. Simpson (2003:367) paints a chilling picture of Saddam as a dictator: 'an inner voice inside everyone's head, a permanent twenty-four-hour-a-day terror. There was nowhere where you could be safe from him, no moment where you could relax.' It should be noted that Saddam's childhood would also have shaped his worldview. Saddam's shame of his humble origins drove his ambitions and, as Coughlin (2002:1) notes, the deep sense of insecurity that he developed as a consequence of his disadvantaged childhood left him incapable of trusting anyone. From his experience, Saddam learnt that in the violent world of Iraqi politics, physical force was indispensable for attaining power and then maintaining it (Karsh \& Rautsi, 1991:24). Aburish (2002:64) argues that Saddam's ideology was shaped in part by tribal instincts.

${ }^{10}$ For example, Saddam has made videotapes of his atrocities and had them distributed to instill fear into his opponents. 


\section{Demands of loyalty}

Loyalty to the ruler was a cornerstone of Mesopotamian civilization. This concept of loyalty reached its height during the Neo-Assyrian empire where disloyalty was never an option. Loyalty oaths were imposed upon everyone - from the royal family to ordinary subjects. Kuhrt (1997:515) sums up the duties laid upon those swearing the oath: total loyalty to Assyria and its kings and to defending the political status quo. This included averting all conspiracies, revolts, assassination attempts, and the obligation to report anything that might affect the safety of king or country. Punishment for breaking the oath included ripping out tongues, flaying alive and exposure to wild animals (Kuhrt, 1997:516).

Darwish and Alexander (1991:87) describe Saddam as a ruthless dictator who demanded loyalty. Disloyalty was severely dealt with in the manner of the Assyrian kings. Karsh and Rautsi (1991:151) note that members of the National Assembly signed their oath of allegiance to Saddam in their own blood, and even family members were encouraged to spy on each other for breaches of loyalty.

\section{Propoganda}

Roaf (1990:71) points out that even as early as the fourth millennium, art was used to portray the Mesopotamian ruler and reinforce his position. Art, as well as architecture, combined to produce an effect of great power and wealth in order to impress the local population. The Uruk kings appear in various roles on seals including feeding flocks, defeating the enemy and providing for temples (Collon, 1995:51). The kings of Akkad ensured that their presence was marked throughout the empire by life-like royal statuary set up in city-shrines (Kuhrt, 1997:54). A considerable number of statues of Gudea (c.2170) of Lagash have been excavated in which there is an emphasis on the physical splendour of the king.

By the first millennium, the kings relied heavily on the use of art to bolster their image. Holloway (2002:382) notes that the Assyrians 'exploited the visual communicative arts with an almost modern feel for ideological impact, usually exercised in the service of imperial aggrandizement and intimidation'. A sequence of reliefs shows Ashurbanipal (668-c.630) taking part in the royal hunt. They depict the kings' prowess with various weapons as well as him making an offering to the gods (Collon, 1995:152-153). 
Apart from art, literature was also used to underpin the position of the king. The unprecedented centralisation of power under the kings of Akkad needed an entirely new propaganda apparatus and scribes were centrally trained and posted to the provinces to run local bureaucracies (Michalowski, 1995:2282). The sudden rise of the dynasty of Akkad led to the rapid creation of an extensive body of legendary and epic material which illustrated the ideological and symbolic importance of the kings $^{11}$ (Kuhrt, 1997:47).

Evidence for the development of kingship ideology and its divine aspects in the Ur III state comes from the royal hymns. Although each is different, they all emphasise the legitimacy of the king.

During the Old Babylonian period royal scribes 'glorified the conquest of power now not by cities but by kingdoms and empires through the warlike deeds of kings who felled enemies as well as rivals' (Bottero, 1995:2296). The epics of Zimri-Lim (1775BC) of Mari fall into this category. The reign of Tiglath-pileser I (1114-1076BC) saw the development of the Assyrian annals, which chronologically memorialised the achievements of the Assyrian ruler. This type of royal inscription ${ }^{12}$ continued until the very end of the Neo-Assyrian empire five hundred years later (Kuhrt, 1997:358). In these, the king is depicted, among other things, as pious and blessed by the gods, protecting the arrangements made by them (Kuhrt, 1997:360). His military exploits and hunting skills are also glorified (Kuhrt, 1997:360). Kuhrt (1997:476) asserts that the images of Assyrian kingship and power propagated by the royal annals were not simply hidden from sight, but played an important role in spreading their message to a wider public. They were written to become known by subjects and enemies alike and were written for 'self-justification, or to obtain or increase socio-political control, or to mobilize, or to impress, or even to frighten' (Liverani, 1995:2354).

Soon after Saddam assumed the presidency, the Iraqi people were exposed to images of their omnipotent, omnipresent, fatherly leader, who was portrayed as strict but righteous. Images of the leader appeared everywhere (Karsh \& Rautsi, 1991:121). Public buildings in Baghdad were intended to glorify Saddam, many having photographs of him on their walls. The photographs portray the leader in various heroic, leadership and humanitarian roles just as the ancient kings portrayed themselves in their reliefs.

\footnotetext{
${ }^{11}$ Postgate (1995:395) notes that any account of Mesopotamian ideology must be one-sided and partial and that 'we can write about the nature of political regimes at all is only by courtesy of what they wrote themselves'.

${ }^{12}$ The royal inscriptions, though autobiographical, were not the works of the king himself, but of the court scribes and poets.
} 
Many episodes of Saddam's early life as described by his official biographers, modern-day scribes, incorporate a degree of mythology showing Saddam to be heroic, strong and brave (Coughlin, 2002:49). Although the coup of 1968 which finally brought the Ba'ath Party to power was a relatively civil affair, Saddam's version of his role in the event had been exaggerated (Coughlin, 2002:49). It was also glorified in numerous publications, television programmes and even in a film (Karsh \& Rautsi, 1991:18). The story contains all the elements of a heroic leader: patriotism, courage, manliness and iron discipline.

For relaxation, Saddam liked to go hunting and, like the kings of Mesopotamia, he enjoyed a reputation as a good shot. Through the years, Saddam nurtured the popular myth of his mastery of the pistol (Karsh \& Rautsi, 1991:166), and his official biographies boast his genius in handling firearms from the age of ten (Darwish \& Alexander, 1991:198).

Saddam himself has written a few novels. His first book is entitled Zabibah and the King. Like the epics of the Mesopotamian rulers, Saddam is portrayed in the novel as a heroic king who defeats his evil enemies; in this case the enemy is America. He spent the final weeks before Gulf War II writing Be Gone Demons, a novel in which he again casts himself as a heroic leader.

The propaganda machinery in Saddam's Iraq, it should be noted, was much more powerful than that of the Mesopotamian kings, reaching to every corner of Iraq. Saddam used the state-run television and radio as vehicles for his propaganda. Literacy levels are much higher in modern Iraq than in ancient times and the government-controlled press also played a significant role in spreading Saddam's propaganda. Furthermore, teachers were forced to join the Ba'ath Party in order to ensure the indoctrination of pupils. Mass education did not exist in ancient times. It is also important to note that unlike the ordinary Mesopotamian citizen, modern Iraqis have a greater availability of news from outside the country and within a shorter time period. Even in the remotest village Iraqis obsessively listen to foreign radio stations in Arabic, including the BBC and Voice of America (Cockburn \& Cockburn, 2002:xxi). Hence an awareness of their position within the context of the wider world is far greater with modern Iraqis than ancient Mesopotamians. Furthermore, the urbanisation of tribes has made it easier for Saddam's regime to address previously difficult to reach communities (Henderson, 1991:31).

\section{The religious role of the ruler}

Berlin (1996:1) points out that in Mesopotamia the religious aspects of politics and the political aspects of religion became intertwined in intricate ways. 
Mesopotamian kingship from the beginning had a very definite religious dimension. Kingship was viewed as one of the basic institutions of human life, fashioned by the gods for humankind. The gods were believed to have chosen the king or 'taken his hand'. The gods were also seen as playing a part in his creation, birth and upbringing (Nemet-Nejat, 1998:218). The ruler's privileged relationship with the gods brought divine help, blessing and good fortune to the land in return for his ceaseless attention to the deity's needs.

Ba'ath Party ideology insisted that state and religion be kept separate. However, while the two may, in theory, be separate, politics and religion are related, somehow, and in some way. During the war with Iran, Saddam claimed that his party was not opposed to religion, but in fact 'derived its spirit from heaven' (Karsh \& Rautsi, 1991:151). He argued that Islam and Arab nationalism were indivisible and that he, the direct descendent of the Prophet, was the man best suited to embody the immortal bond between Islam and Arab unity (Karsh \& Rautsi, 1991:152).

In 1990-1991, the secular Saddam, finding himself at war, inscribed Allahu Akbar on the national flag and, after seeing the Prophet in a dream (the gods frequently spoke to the ancient kings in their dreams), declared jihad against the infidels (Lewis, 1993:184). At the same time, Saddam saw to it that he was photographed and filmed praying in mosques (Simpson, 2003:251).

However, an important distinction needs to be made between the two eras. As the king was the earthly representative of the divine, politics and religion were aspects of Mesopotamian culture that could not be separated from the other. Saddam, on the other hand, looked to religion only when it was politically convenient and the examples mentioned above were opportunistic attempts to garner support. It must be pointed out that Saddam drank alcohol and initiated the reintroduction of horse-racing; both activities are un-Islamic (Coughlin, 2002:102104).

\section{Warfare}

From Early Dynastic times, relations with neighbouring Elam (which was to become Persia, and later Iran) were marked by conflict. The so-called 'VultureStele' shows Eanatum (c.2450), king of Lagash, defeating the people of Elam. The army was led by the king; a major factor in the pre-eminent status of the king was his prominent military role.

The concept of divine war was central to the worldview of the Mesopotamians. In a divine war the gods are active in the war and the outcome of 
the battle is determined by them. Victory was won at the will of the god of the successful king. A constant theme in ancient warfare was that the enemy had sinned against the gods of his opponents, and victory over the sinner was seen as the triumph of justice (Dalley, 1995:416). During the time of the Empire of Akkad, the military grew in size and complexity. Soldiers were provided with food rations, wool and weapons, and some were given plots of land for subsistence (Kuhrt, 1997:55). Sargon's (2296-2240BC) army, it seems, depended directly on him and was largely fed by him, thereby guaranteeing the loyalty of the troops (Franke, 1995:832).

One of the duties of the king was to fight wars and his role as warrior is one of the most important aspects of Assyrian kingship. A command issued by the god Ashur to his earthly representative, the Assyrian king, was for the king to enlarge the frontiers of Assyria. Assyrian theology rested on the god Ashur's claim to universal rule. In other words, war was viewed as a divine commandment and never as an act of pure military aggression. As the god Ashur was supreme in the Assyrian pantheon, so the Assyrian king was exalted above all other earthly rulers (Knapp, 1988:225). The Assyrian king was conceptualized as embodying a moral force - he knew what was right and what was wrong. The early Neo-Assyrian kings saw their campaigns as reasserting their control over regions that were rightfully theirs (Kuhrt, 1997:479).

The greatest military era in Assyria's history commenced with the ascension to the throne by Tiglath-pileser III. He established a disciplined army made up of both professional soldiers and national militia. Every male was under obligation to perform military service when called upon. By the reign of Ashurbanipal, constant fighting had slowly drained Assyria's manpower. The state began to rely increasingly on mercenaries from conquered peoples to beef up the army. As a result, by the late Assyrian empire, the majority of troops were not Assyrian (Grayson, 1995:960). Keegan (1993:172) notes that Assyria seems to have been the first power to recruit troops without ethnic discrimination, but the loyalty of nonAssyrian soldiers is questionable.

Assyria's conquest of its neighbours followed a fixed pattern. The Assyrians first received gifts from independent rulers who then assumed client status. Failure to provide suitable tribute was regarded as rebellion, provoking mobilization of the Assyrian army. After conquest, either a local ruler was appointed as a vassal of Assyria or the country was annexed as a province under a governor appointed by the king (Roaf, 1990:160).

Esarhaddon (680-669BC), in a letter written to the king of Shupria, which preceded a war with that country, presents himself as a powerful head of state 
making a reasonable 'request' to the ruler of a small neighbouring country. The Shuprian king's refusal to meet this request becomes the casus belli, and the Assyrian king has no option but to go to war (Kuhrt, 1997:510).

As Iraq's president, Saddam saw no reason why he could not become a significant figure in international affairs. He firmly believed that it was the destiny of Iraq to be the pre-eminent force in Middle East politics (Coughlin, 2002:125). Saddam called himself 'the leader of the Arab nation' and, according to Pollack (2002:150), he made it clear that this role would be a political-military one, meaning that he, like the Mesopotamian monarchs, would achieve this position through some combination of conquest and acclaim. His vision was to create a united Arab republic, headed by him.

His desire to dominate international affairs required that Iraq develop its military strength. All males from the age of eighteen to forty were conscripted for two years into the army. Saddam created his own intelligence service as well as his own army unit which owed its allegiance solely to the president. This was to become the Republican Guard. They received better training and salaries than the other soldiers and, like Sargon's men, were totally dependent on the ruler for their existence. Saddam's link to Mesopotamia is evidenced by the fact that one of the most powerful divisions of the Iraqi army was the Hammurabi Republican Guard Armored Division, and a further unit, the Nebuchadnezzar Infantry Division.

As mentioned earlier, there have been many conflicts between the lands of Iran and Iraq from the earliest times of recorded history, and the two modern-day countries had, even before the Iran-Iraq war, engaged in border clashes for decades. A motive for the war, shared by both countries, was to determine which of the two would become the dominant power in the region. Saddam has always sought to be the leader of a pan-Arab movement. Sciolino (1991:111) quotes Saddam as saying that 'the Koran was written in Arabic and God destined the Arabs to play a vanguard role in Islam'. He also twisted a Koranic verse to state that Arabs were 'the best nation among mankind' (Sciolino, 1991:111). These claims bear a resemblance to those made thousands of years earlier by the Assyrian kings. ${ }^{13}$

Saddam had a similar problem as the Assyrian kings regarding his troops in that many of the Iraqi soldiers were Shi'ites and there was no guarantee of their

\footnotetext{
${ }^{13}$ Saddam's conflicting approaches to achieve his goals saw him, during the war with Iran, focus on the concept of Iraqi nationalism with pan-Arabism taking second place. This was done to motivate Iraqis to support the war. In the early 1990 s, in an attempt to forge new alliances, although in conflict with Arab nationalism, Saddam went to great lengths to conciliate tribal leaders across the country, including handing out cars to Shi'ite tribal sheikhs (Cockburn \& Cockburn, 2002:149).
} 
loyalty especially when required to attack fellow Shi'ites in Iran. By the end of the long war, and after thousands of casualties on both sides, neither country emerged as clear victor. This, however, did not stop Saddam from claiming a magnificent victory.

With the economy in ruins following the war with Iran, Saddam began planning a move that would restore the country's finances. This included virtually demanding that the Gulf states bail him out of his financial difficulties (Coughlin, 2002:247), a demand akin to those made by the ancient kings for tribute from their smaller neighbours. Kuwait received special attention from Saddam. Kuwait, in his view, had a historic obligation to support Iraq. He pointed out that Kuwait had been illegally separated from Iraq by the British in the 1920s when they drew up Iraq's boundaries. In a final attempt to intimidate Kuwait, Saddam handed the country a list of demands, which, if not met, would be followed by Iraqi reprisals. Kuwait's response was not to Saddam's liking and his army invaded Kuwait. The whole episode reminds one of Esarhaddon's war with Shupria.

On August 28, 1990, Kuwait officially became the nineteenth province of Iraq. Saddam appointed one of his cousins as governor of Kuwait. The annexation of an independent country and the appointment of a puppet ruler also remind one of the policy of the Mesopotamian kings. In invading Kuwait, Saddam hoped, among other things, to enhance his national prestige by portraying himself, like the early NeoAssyrian kings, as the liberator of usurped Iraqi lands.

The invasion prompted swift action by the international community resulting in what became known as the Gulf War. In the build up to the Gulf War, Saddam, anticipating divine favour, warned the coalition forces, led by America, that 'the Iraqi people are capable of fighting to the victorious end which God wants ...' (Karsh \& Rautsi, 1991:222). A transcript of a secret meeting between senior army officers inside Kuwait in October 1990 during the countdown to the Gulf War reveals that Saddam claimed that he, like the Mesopotamian kings, was given orders from heaven to invade Kuwait: 'May God be my witness, that it is the Lord who wanted what happened to happen. This decision we received almost ready-made from God ... Our role in the decision was almost zero' ('Abd-al-Jabar, 1994:104). When the coalition forces had broken his army in the war, Saddam told his supporters that 'angels of mercy' would come to their rescue to compensate them for the air cover they lacked (Ajami, 2003:389), further evoking a belief in divine favour. It must be pointed out again that Saddam's religious utterances were purely opportunistic in contrast to the institutionalised role religion played in Mesopotamian politics. 


\section{Propaganda during war}

Throughout Mesopotamian history the kings, through their scribes, enhanced their warrior image and the might of their realm through propaganda. The ancient writings are full of war propaganda and a few examples from the Neo-Assyrian empire will suffice here. The Assyrian people had to be convinced that imperial expansion was desirable and justified and were subjected to constant propaganda in this regard (Knapp, 1988:225).

The Assyrian kings adopted a policy of complete blackout in the case of their own military defeats and according to the royal inscriptions, the Assyrians never lost a battle (Holloway, 2002:92). In their annals Assyrian defeats were either ignored or claimed as victories (Roaf, 1990:159). In the long, drawn-out conflict with Rusa I (c.714) of Urartu, in which Sargon II was eventually victorious, the Assyrian ruler claimed in a letter to the god Ashur, that only one charioteer, one cavalryman and three foot soldiers in his army were killed! (Roaf, 1990:182). In his inscriptions and reliefs, Sennacherib (704-681BC) portrayed himself as a successful and invincible monarch, though, in reality, as Roaf (1990:185) points out, his reign was marked by a series of uprisings and defeats.

Horowitz (2002:149) notes that in the eight years of the Iran-Iraq War, no Iraqi defeats and no Iraqi casualties were ever reported. At the same time, there were regular reports in the state-run media of the 'thousands of enemy casualties' (Horowitz, 2002:149). Iraq, according to Saddam, engaged in a 'voluntary withdrawal' from Iran in the summer of 1988. This was how he referred to the setbacks his country had suffered at the hands of the Iranians. When the war was over, Saddam simply declared himself the victor. In spite of an estimated one million fatalities and a wrecked economy, the war was proclaimed as a triumph for the Iraqi people.

A day after the outbreak of Gulf War I Saddam claimed that his forces had shot down sixty allied aircraft and proclaimed victory (Karsh \& Rautsi, 1991:245). Despite early losses Saddam appeared confident. Coughlin (2002:268) quotes him in warning his attackers that '... the deaths on the allied side will be increased with God's help'. In his speeches during the war Saddam argued that the world is a testing ground and that God created it in order to see which of God's creations will outdo the others in doing good (Kelsay, 1993:14). In this way humanity's destiny was to command good and forbid evil and to establish a just social order. In Saddam's eyes, this destiny was to be fulfilled by the Islamic Arab nation (Kelsay, 1993:14). He described the confrontation between Iraq and the coalition forces as 'the war of right against wrong and a crisis between Allah's teachings and the devil' (Kelsay, 1993:16). Like the Assyrian kings, Saddam believed that he embodied all 
that was 'right' and that the enemy was the personification of 'evil'. And like the ancient monarchs he believed that he was responsible for maintaining the order that the gods had created.

Even as his army was being routed during the land battle in Kuwait, Coughlin (2002:273) quotes Saddam as boasting: 'You have faced 30 countries and the evil they have brought here. You have faced the whole world, great Iraqis. You have won. You are victorious'. According to Saddam, his defeat in the war had been an orderly, planned withdrawal. During Gulf War II, even as Iraqi troops were incurring heavy losses in Baghdad the Iraqi Information minister, a modern-day scribe, declared that: 'Baghdad is safe. The battle is going on. The infidels are committing suicide by the hundreds on the gates of Baghdad.....' (Ramesh, 2003:165-166). The minister remained loyal to his leader to the very end. ${ }^{14}$ His denials of reality included informing the world that coalition troops were not even within one hundred miles of Baghdad even as the city's airport fell (Simpson, 2003:320). It should be pointed out that these distortions of reality were not unique to the Mesopotamian kings and Saddam - the lies of war propaganda have characterised military conflicts throughout history.

Karsh and Rautsi (1991:44-145) describe Saddam's attempts to gain Shi'ite support during his war with Iran. Saddam, until then a secularist leader, began to laud their patron Imam and claimed to be a staunch follower of his. To 'prove' this he staged numerous television visits, dressed in traditional Shi'ite attire, to Shi'ite settlements. The birthday of Imam Ali (d.661), the founder of the Shi'ite tradition, was declared a public holiday. Saddam further made attempts to appease the Shi'ites by maintaining and repairing their shrines (Karsh \& Rautsi, 1991:163). The money for this, he claimed, came from his own pocket (Henderson, 1991:201). To further convince the surprised Shi'ite community of his transformation, he produced 'evidence' in the form of a genealogical table linking himself to the very heart of Shi'ism. It is clear that Saddam's religious rhetoric was opportunistic in an attempt to gain advantage during war. In Mesopotamia, religious references related to war formed an integral part of the system.

\section{Building projects}

One of the rulers' most important duties was to ensure that temples were built, restored if required, and luxuriously equipped. To the last Mesopotamian

${ }^{14}$ The allied forces defeated the Iraqi army and captured Saddam in December 2003. At the time of writing, allied forces were attempting to bring order to the country after the first round of democratic elections, which were held in January 2005. 
dynasty in 539, the kings included their care for temples among their principal titles. As early as the Uruk phase in the fourth millennium, elaborate temple buildings were used by emerging power groups to secure their pre-eminent position (Kuhrt, 1997:25). The kings were often depicted carrying a basket of earth for the building or rebuilding of temples.

The most striking witness to the reign of Ur-Nammu (2112-c.2095) are the ziggurats - stepped towers that had temples on their highest levels. Many of the bricks used bear stamped inscriptions telling us that the builder was Ur-Nammu (Nissen, 1988:190). The might and splendour of the king was also reflected in the palaces that they built. From Sumerian times kings lived in large palaces, symbols of their power. Many of these buildings were beautifully laid out and handsomely decorated.

Saddam spent huge amounts of money in the building of several giant mosques. One of the biggest and most expensive was the Umm al-Maarik or 'Mother of all Battles Mosque' in central Baghdad which was completed in time for his birthday celebrations in 2001, the tenth anniversary of Gulf War I (Coughlin, 2002:315). Simpson (2003:63) describes Saddam as 'an inveterate builder of monuments to himself'. One of his numerous painted images shows Saddam, like a Mesopotamian king, as a construction worker carrying a bowl of wet cement on his shoulder. Saddam also built numerous palaces throughout the country, even in the most remote areas (Coughlin, 2002:228). Of course, Saddam's more developed bureaucracy and the modern technology available to him afforded him a far greater ability in his building projects. Also important to note is that while the kings' building projects had a religious component, Saddam's were purely for propaganda and self-glory.

\section{The ruling family and favoured subjects}

Towards the end of the Early Dynastic period, the earlier system of elective kingship was replaced by the dynastic system of royal succession (Hallo \& Simpson, 1998:46). While details of city government are not well known, it is evident that the most important functions of state were filled by members of the royal family and their relatives. In the Empire of Akkad, local ensi were replaced with Akkadian governors loyal to the king (Charpin, 1995:810). It would appear the members of the imperial government came from the court and royal family. Relatives of Sargon filled numerous high offices. However, as the posts were numerous, those that could not be filled by family members were given to men who owed their primary allegiance to the king (Hallo \& Simpson, 1998:55). 
As a general rule, the king selected his eldest son to succeed him, but this was not always the case. In Assyria, the son chosen to succeed his father was increasingly given responsibilities in running the empire as part of his grooming for future royal duties (Kuhrt, 1997:522). The successor's education included military training. Senior military personnel came either directly from the royal family or had married into it (Kuhrt, 1997:61). Nebuchadnezzar II's (604-562BC) eldest daughter was married to Neriglissar (559-556) one of his generals, who later seized the throne (Kuhrt, 197:605). The high personages surrounding the king were extremely wealthy; they could be granted extensive estates by him, free of taxes (Kuhrt, 1997:531).

In the tradition of the Mesopotamian kings, Saddam appointed his stepbrother, Adnan Khairallah as Minister of Defence. He married one of his daughters to a cousin, who was head of the Ministry of Industry and Military Industrialisation, and another daughter was married to a cousin who was a colonel in the missile brigade (Sciolino, 1991:57). But it must be noted that marrying within the family was the norm for Iraqis who shared Saddam's background. Saddam's cronies were given important political posts in return for their unconditional loyalty and obedience to him. Saddam's family, friends and other high-ranking officials received huge perks. Members of the security services and the Republican Guard got better pay, cars and other material benefits (Pollack, 2002:114). Coughlin (2002:204) points out that it has become the habit of secular Arab despots, like the ancient kings, to groom their sons as their political heirs. In 1984, Uday (19642003), Saddam's elder son, was appointed director of Iraq's Olympic Committee. This was essentially a position to enable Uday to learn the art of government in the manner of the Assyrian appointed successor. And like the ancient appointed successor, he was also given responsibilities and trained to be a warrior. At the beginning of the Iran-Iraq war, Uday used to go to the front accompanied by the Iraqi chief of staff. ${ }^{15}$ Uday has boasted that he and his younger brother, Qusay $(1966-2003)^{16}$, were taken by their father to Iraqi prisons to watch torture and executions as part of a 'toughening up' process (Kaplan \& Kristol, 2003:9).

\footnotetext{
${ }^{15}$ Cockburn and Cockburn (2000:152) note, however, that he was never put in a high-risk situation.

${ }^{16}$ Both brothers were killed in a shoot-out with American soldiers after the fall of Saddam's regime.
} 


\section{Divination}

In Mesopotamia, the kings were viewed as holding office by the grace of the god of their city or land on whose behalf they ruled. Special measures were taken to protect the king from perceived dangers and these tasks were undertaken by priests and diviners. In the later priesthood, the role of these individuals grew in importance and they can be regarded as an arm of the Mesopotamian monarch (Hallo \& Simpson, 1998:176).

Coughlin (2002:298) reports that Saddam relied on a number of psychics to warn him of any impending danger. He made particular use of an elderly blind woman psychic in times of crisis. She once prophesised that he would be the victim of an assassination attempt (a fairly common occurrence during his reign), and he thereafter trusted her judgment. Pollack (2002:235) reports that it was rumoured that Saddam relied on soothsayers more than his intelligence services. It should be noted that Saddam most probably inherited his superstitious nature from his mother who was a prophetess in her village (Coughlin, 2002:298).

\section{Seeking a link with the past}

Mesopotamian rulers constantly sought to look to the past in their attempts to underpin their legitimacy. Kuhrt (1997:59) suggests that the Uruk epics about Gilgamesh and other early kings were given their classic Sumerian form during the Ur III period. The kings of the Ur III state repeatedly linked themselves to these earlier kings through mythical family ties. In one text Ur-Nammu presents gifts to 'his brother, Gilgamesh' (Kuhrt, 1997:59). The victory over Elam by Nebuchadnezzar I (1126-1105BC) prompted him to foster an image of his greatness by adopting older royal titles in the style of Sargon and Hammurabi. He also revived the antique practice of installing his daughter as priestess of the moon-god at Ur. As Kuhrt (1997:378) notes, 'these acts illustrate, strikingly, an awareness of earlier Mesopotamian history, and how it could be used to stress continuity with a more glorious past ...'. Hundreds of years later, Neo-Babylonian king Nebuchadnezzar II also revived the ancient practice of installing a royal daughter as priestess. The king miraculously 'found' an earlier royal text providing him with the details of the induction ceremony. Kuhrt (1997:598) points out that a number of Nabonidus' (555539BC) inscriptions contain historical retrospects intended to show that his violent seizure of the throne had the blessing of earlier Babylonian kings. He also makes recurring references to his search for earlier buildings in the course of his own construction work. He is said to have found a broken statue of Sargon of Akkad and had it repaired and set up in a temple (Kuhrt, 1997:598). 
Saddam thinks of himself as a great man of history, someone destined to accomplish great deeds. The Saddam personality cult compares him to the great figures of the country's past. These historical references, according to Pollack (2002:150), are crucial to Saddam who is obsessed with history and his role in it. He views Iraq as the manifestation of its glorious past. Thus he constantly employs names and myths from ancient times to justify his actions. Saddam, during his war with Iran, in an attempt to portray himself as the rightful leader of Arab nationalism, described Nebuchadnezzar as 'an Arab from Iraq' who fought against Persians and Jews (Karsh \& Rautsi, 1991:152). At the end of the war he paid tribute to Nebuchadnezzar and other great figures from antiquity by holding official burial ceremonies for the remains of the ancient kings and building new tombs on their graves (Coughlin, 2002:227). He also began with a massive reconstruction of the site of ancient Babylon. Large parts of the ancient ruins were torn down and replaced by yellow-bricked walls. Thousands of the bricks used bore an inscription, like the bricks the Mesopotamian kings used in the building of their temples. Saddam's bricks read: 'Babylon of Nebuchadnezzar was rebuilt in the era of the leader President Saddam Hussein' (Coughlin, 2002:227).

The emblem of the 1988 Babylon International Festival showed the profile of Saddam overlapping that of Nebuchadnezzar ${ }^{17}$ (Sciolino, 1991:51). During his birthday celebration each year, Saddam chose a different historical hero to emulate. In 1990 he chose Sargon of Akkad.

The Mesopotamian theme made its presence felt in modern Iraqi art, architecture and everyday life. The regime sponsored local festivals based on ancient rites, official buildings were decorated with Assyrian reliefs and governmentsponsored fashion shows dressed women in Assyrian-inspired ball gowns (Sciolino, 1991:51).

It should be pointed out that the regime rewrote history to suit its own needs. Mesopotamian history was 'Arabised' and portrayed as part of the Iraqi heritage ${ }^{18}$ (Karsh \& Rautsi, 1991:123). It was not only the Mesopotamian kings that Saddam compared himself to. The Iraqi propaganda machine looked to the entire history of the region to portray Saddam in various guises depending on the political climate of

\footnotetext{
${ }^{17}$ Saddam's nose was elongated to make him better resemble the Mesopotamian king.

${ }^{18}$ Saddam was not the first leader in the region to manipulate the cultural heritage of his country to lend legitimacy to his rule. Kemal Attaturk (1881-1938), Turkey's nationalist leader for much of the 1920s and 1930s, looked to the Sumerians and Hittites in an attempt to convince his countrymen that the culture and civilizations of all nations flowed from the Turkish homeland. Shah Mohammad Reza Pahlavi (1919-1980) of Iran, who ruled between 1956 and 1979, presented himself as a modern-day Cyrus the Great (559-530BC) of Persia (Sciolino 1991:40).
} 
the time (Darwish \& Alexander, 1991:215). Saddam is the new Nasser (1918-1970), Saladin (1138-1193) ${ }^{19}$, the Prophet Mohammed (c.570-c.632), and various caliphs of the region.

\section{Conclusion}

Whether they ruled over a city-state in the earlier stages of Mesopotamia's history, or the empires of the first millennium, the kings had many aspects of ideology in common. The regime of Saddam Hussein, centuries later, also embraced many of those aspects of ideology. In their absolute power and violence employed to ensure it, in their propaganda to prove their legitimacy and to portray themselves as relentless builders and victorious warriors, in their quest to dominate their neighbours through god's help, in their desire for eternal fame, and, in their need to see themselves as part of an ancient and magnificent heritage, Saddam and the Mesopotamian kings had much in common.

However it should also be noted that Saddam's ideology varied according to circumstances. Karsh \& Rautsi (1991:268) argue that Saddam carried no ideological baggage: ideology for Saddam, they assert, was purely a means of ensuring that he retained the country's top position for as long as he could. He would 'use whatever ideological acrobatics (that) were required to achieve this objective' (Karsh \& Rautsi, 1991:268). It might be argued that Saddam's practices were determined more by opportunism than ideology.

Apart from Mesopotamians, Iraq has seen Hittites, Medes, Persians, Greeks, Romans, Parthians, Arabs, Mongols, Ottoman Turks and the British all pass through it; and all have left their mark on the land in some way (Murray \& Scales, 2003:17). Many of Saddam's practices discussed in this article may also be likened to the empires that followed Mesopotamia. It would be fair to say that Saddam used political methods that are common to most autocracies, both ancient ${ }^{20}$ and modern ${ }^{21}$. While there were indeed similarities between Saddam's rule and that of the Mesopotamian monarchs, there were differences as well. Saddam's Iraq was a different world to that of the ancient rulers of the region and Saddam's ideology reflected his specific conditions.

\footnotetext{
${ }^{19}$ That Saladin was a Kurd did not matter to Saddam.

${ }^{20}$ Including those outside the ancient Near East.

${ }^{21}$ Saddam's rule has been likened to those of Stalin (1879-1953), Ceausescu (1918-1989) and Kim Jong Il (1942- ).
} 
Scientia Militaria, South African Journal of Military Studies, Vol 33, Nr 1, 2005. doi: 10.5787/33-1-3

History, though, has repeated itself in the sense that Saddam is the latest in a long line of rulers, going back millennia, who, after establishing and entrenching their positions in the region through violence, were themselves overthrown by violence.

\section{BIBLIOGRAPHY}

'Abd-al-Jabar, F. 1994. Why the intifada failed. In Hazelton, F (ed). Iraq since the Gulf War: Prospects for democracy, 97-117. London: Zed.

Aburish, S.K. 2002. Cruel ancestry. In Miller, J \& Kenedi, A (eds). Inside Iraq, 6374. New York: Marlow.

Ajami, F. 2003. Two faces, one terror. In Sifry, M L \& Cerf, C (eds). The Iraq war reader: History, documents, opinions, 387-391. New York: Touchstone.

Berlin, A. (ed). 1996. Religion and politics in the ancient Near East. Bethesda: University of Maryland Press.

Bottero, J. 1995. Mesopotamia: Writing, reasoning, and the gods. London: University of Chicago Press.

Bottero, J. 2001. Religion in ancient Mesopotamia. Chicago: University of Chicago Press.

Charpin, D. 1995. The history of ancient Mesopotamia: An overview. In Sasson, J M (ed). Civilizations of the ancient Near East. Volumes I-IV, 807-829. New York: Charles Scribner's Sons.

Cockburn, A. \& Cockburn, P. 2000. Out of the ashes: The resurrection of Saddam Hussein. New York: Verso.

Cockburn, A. \& Cockburn, P. 2002. Saddam Hussein: An American obsession. London: Verso.

Collon, D. 1995. Ancient Near Eastern art. London: British Museum Press.

Coughlin, C. 2002. Saddam: The secret life. London: Macmillan.

Dalley, S. 1995. Ancient Mesopotamian military organisation. In Sasson, J M (ed). Civilizations of the ancient Near East. Volumes I-IV, 413-422. New York: Charles Scribner's Sons.

Darwish, A. \& Alexander, G. 1991. Unholy Babylon: The secret history of Saddam's war. London: Victor Gollancz. 
Scientia Militaria, South African Journal of Military Studies, Vol 33, Nr 1, 2005. doi: 10.5787/33-1-3

Franke, S. 1995. Kings of Akkad: Sargon and Naram-Sin. In Sasson, J M (ed). Civilizations of the ancient Near East. Volumes I-IV, 831-841. New York: Charles Scribner's Sons.

Grayson, A.K. 1995. Assyrian rule of conquered territory in ancient Western Asia. In Sasson, J M (ed). Civilizations of the ancient Near East. Volumes I-IV, 959-968. New York: Charles Scribner's Sons.

Hallo, W.W. \& Simpson, W.K. 1998. The ancient Near East: A history. Second edition. Fort Worth: Harcourt Brace.

Henderson, S. 1991. Instant empire: Saddam Hussein's ambition for Iraq. San Francisco: Mercury House.

Hiro, D. 2002. Iraq: A report from the inside. London: Granta.

Holloway, S.W. 2002. Aššur is king! Ǎ̌šur is king!: Religion in the exercise of power in the Neo-Assyrian empire. Leiden: Brill.

Horowitz, T. 2002. In the land without water. In Miller, J \& Kenedi, A (eds). Inside Iraq, 145-166. New York: Marlow.

Kaplan, L.F. \& Kristol, W. 2003. The war over Iraq: Saddam's tyranny and America's mission. San Francisco: Encounter.

Karsh, E. \& Rautsi, I. 1991. Saddam Hussein: A political biography. London: Brasseys.

Keegan, J. 1993. A history of warfare. London: Hutchinson.

Kelsay, J. 1993. Islam and war: the Gulf war and beyond: a study in comparative ethics. Louisville: Westminster.

Knapp, A.B. 1988. The history and culture of ancient Western Asia and Egypt. Belmont: Wadsworth.

Kuhrt, A. 1997. The ancient Near East c.3000-330 BC. Volumes I-II. London \& New York: Routledge.

Lewis, B. 1993. Islam and the west. New York: Oxford University Press.

Liverani, M. 1995. The deeds of ancient Mesopotamian kings. In Sasson, J M (ed). Civilizations of the ancient Near East. Volumes I-IV, 2353-2366. New York: Charles Scribner's Sons. 
Scientia Militaria, South African Journal of Military Studies, Vol 33, Nr 1, 2005. doi: 10.5787/33-1-3

Michalowski, P. 1995. Sumerian literature: An overview. In Sasson, J M (ed). Civilizations of the ancient Near East. Volumes I-IV, 2279-2291. New York: Charles Scribner's Sons.

Millar, J. \& Mylroie, L. 2003. The rise of Saddam Hussein. In Sifry, M.L. \& Cerf, C. (eds). The Iraq war reader: History, documents, opinions, 18-29. New York: Touchstone.

Murray, W. \& Scales, R.H. 2003. The Iraq war: A military history. Cambridge: Belknap.

Nemet-Nejat, K. 1998. Daily life in ancient Mesopotamia. Peabody: Hendrickson.

Nissen, H.J. 1998. The early history of the ancient Near East 9000-2000BC. Chicago: University of Chicago Press.

Pollack, K.M. 2002. The threatening storm: The case for invading Iraq. New York: Random House.

Postgate, J.N. 1977. The first empires. Oxford: Elsevier-Phaidon.

Postgate, J.N. 1995. Royal ideology and state administration in Sumer and Akkad. In Sasson, J M (ed). Civilizations of the ancient Near East. Volumes I-IV, 395-411. New York: Charles Scribner's Sons.

Ramesh, R. 2003. The war we could not stop: The real story of the battle for Iraq. London: Faber \& Faber.

Roaf, M. 1990. Cultural atlas of Mesopotamia and the ancient Near East. Oxford: Phaidon.

Sciolino, E. 1991. The outlaw state: Saddam Hussein's quest and the Gulf crisis. New York: John Wiley \& Sons.

Simmons, G. 1994. Iraq: From Sumer to Saddam. Houndsmills: Macmillan.

Simpson, J. 2003. The wars against Saddam: Taking the hard road to Baghdad. London: Macmillan.

Younger, K.L. 1990. Ancient conquest accounts: A study in ancient Near Eastern and Biblical history writing. Sheffield: JSOT. 